TURIZAM

Volume 21, Issue 4

161-171 (2017)

ORIGINAL

SCIENTIFIC PAPER

\title{
Travel Agents as Market Mavens: An Empirical Study on Travel Agencies in Izmir
}

\author{
Hümeyra DoğruA ${ }^{A^{*}}$, Mehmet Ertaş ${ }^{A}$, Burcu Selin Yılmaz ${ }^{\mathrm{A}}$ \\ Received: November 2017 | Accepted: December 2017 \\ DOI: 10.5937/turizam21-16720
}

\begin{abstract}
Despite the developments in computer-mediated communication after the advent of the Internet, traditional word-of-mouth (WOM) marketing is still influential on consumers' buying decision processes. As one of the WOM influencer groups, market mavens are information providers who affect buying decision of other consumers with their product knowledge and marketplace expertise. The purpose of the study is to examine whether front-line employees working at travel agencies are market mavens or not. A survey of 120 travel agency employees was conducted using a structured questionnaire including open-ended questions as well. Descriptive statistics, parallel test, minimum average partial test, exploratory factor analysis, independent samples $t$-test, and correlation analysis were performed using SPSS 24.0 software. The conclusion of the study revealed that the front line employees in travel agencies had a tendency to give recommendations and share information as market mavens.
\end{abstract}

Key words: Word-of-Mouth, Market Mavenism, Travel Agencies

\section{Introduction}

Increasing costs of promotional activities in a competitive environment cause companies to spend billions of dollars in order to market their products and services (Clark, Goldsmith, 2005). Therefore, it might be useful for companies to find alternative ways to market their products and services by more economical means. Companies can maximize customer equity and assess a better long-term profitability by spending less on customer retention when they acquire customers through WOM instead of marketing-induced channels such as broadcast media (Villanueva et al., 2008). The interpersonal effect of WOM mostly prevails against traditional marketing channels while especially choosing services and new products in the market. Therefore, marketers should exert an effort to build communication channels with interpersonal communicators to reach and influence a more extensive market (Walsh et al., 2004). Interpersonal communicators have indicated three main groups about word-of-mouth marketing on considerable existing literature (Corey, 1971; Schiffman, Kanuk, 2010; Silver-

A Dokuz Eylul University, Faculty of Business, Department of Tourism Management, Kaynaklar Yerleskesi, Buca, Izmir, Turkey

* Corresponding author: humeyra.dogru@deu.edu.tr 
man, 2001). These groups who perform word-of-mouth marketing are early purchasers, opinion leaders and market mavens (Feick, Price, 1987).

Early purchasers are the customers who buy and use the product they recommend and keep an active communication with other consumers since they have information about the product; however, they do not have general information about the market itself (Wiedman et al., 2001). Besides, opinion leaders recommend products and services with the information they have (Solomon et al., 2006) and they encourage consumers to purchase (Goldsmith et al., 2003). Early purchasers and opinion leaders influence other consumers with the specific information and expertise they have about products (Feick, Price, 1987). On the other hand, market mavens, as information sources about market characteristics, are individuals who trust their expertise and opinions and share them with other consumers and additionally give information about shopping (Clark et al., 2008). All three types of influential consumers represent an attractive target for marketers since they are inclined to spread information about products and services in the marketplace (Clark, Goldsmith, 2005).

Accordingly, the purpose of this research is to figure out whether the front line employees in travel agencies as a significant information source in the travel industry are market mavens or not. Although market mavens are studied extensively in literature by various researchers (Clark, Goldsmith, 2005; Elliott, Warfield, 1993; Gauri et al., 2016; Williams, Slama, 1995; Yang, 2013), market maven behavior in tourism industry seems to be a highly overlooked issue. Therefore, this study is predicted to contribute a lot to the existing literature and allow marketers to better understand the behaviors of market mavens in the tourism industry. Tourism marketers, then, might improve their interactions with consumers by promoting products, brands, and companies through market mavens.

\section{Literature Review}

Feick and Price (1987: 85) defined market mavens as "individuals who have information about many kinds of products, places to shop, and other facets of markets, and initiate discussions with consumers and respond to requests from consumers for market information." Unlike early purchasers and opinion leaders, market mavens have a general market-related knowledge and a willingness to share information which is not only product specific (Walsh et al., 2004; Wiedman et al., 2001). They are market information providers who affect buying decisions of consumers seeking advice about a broad variety of products and services (Williams, Slama, 1995). For especially risky products, "market mavenism" is essential to compensate the lack of official market information; dispel risk; control the market; empower consumers; and ultimately, enhance safer consumption experiences (O'Sullivan, 2015). Therefore, market mavens are an essential target for retail marketers, since they find market mavens a more efficient group through which to communicate with other consumers owing to their more generalized knowledge of marketplace information (Schneider, Rodgers, 1993a; Sudbury-Riley, 2016). The study of Walsh and Elsner (2012) revealed that market mavens, compared to non-mavens, engaged in stronger referral behaviour that attracted new customers and generated revenue for the firm.

It is necessary to mention the characteristics of market mavens to understand the market mavenism concept better. Feick and Price (1987) correlated market mavenism with opinion leadership for specific products. Market mavens tend to be early users of new products and brands, to seek information about the marketplace, and provide that information to others. The 
study of Higie, Feick, Price (1987) revealed that market mavens communicated retailer-related information more often than any other reference groups. Regarding marketing channels, market mavens pay close attention to the media (television viewing and radio listening) and they are also open to direct mail advertising (Higie et al., 1987; Schneider, Rodgers, 1993b). Flynn and Goldsmith (2017) studied the relationship between being a market maven and the personality factors of the Big Five theory to distinguish mavens from others and helped explain why they were different. Their research revealed that mavens were "smart shoppers" who seeked bargains, clip coupons and discounts to get the best deals and they purchased more since they were more interested in the marketplace and exposed themselves to more market information. Market mavens are also more price-conscious than non-mavens, and they score high on the perfectionism because they try to buy products of superior quality after an in-depth information search process (Gauri et al., 2016; Wiedman et al., 2001). Market mavens seek to interact with other market mavens more than with non-mavens about product-related and market-related information; however, they pursue a selective network of like-minded market mavens (Lee et al., 2015).

The concept of market mavenism has also been tried to be explained regarding online consumer behavior in the literature under the concepts of eMavens or viral mavens (Ho, Dempsey, 2010; Phelps et al., 2004; Walsh, Mitchell, 2010; Walsh et al., 2002). Walsh et al. (2002) differentiate eMavens from non-eMavens regarding the Internet usage behavior and their motives for using the Internet sites. Being a general marketplace influencer with extensive knowledge as a characteristic of market mavens still exists in a virtual environment as well as a face-to-face context. Moreover, while individuals who spend more time on the Internet share more information with others in their social networks, the interpersonal behavior of the eMaven is characterized by the need for inclusion and the need for affection (Ho, Dempsey, 2010). E-mavens share vital market information and reduce the risks for the consumers who seek safer, more controlled and predictable consumption experiences (O'Sullivan, 2015). Phelps et al. (2004) identified that viral mavens forward the messages only if the message was important or contained something that the sender thought the other person would like it. While some viral mavens share information when they are in the right mood and have the time, some of them mentioned a strong sense of duty to forward the message. From the point of marketers, Walsh and Mitchell (2010) recommended that eMavens might be an inexpensive way of communicating short-term marketing messages and disseminating price-related information because they were knowledgeable on marketing-mix information such as price changes and temporary special offers.

Slama, Nataraajan, and Williams (1992) explored maven motivations for passing information. Their study revealed that market mavens had both interest in the marketplace and a friendly personality which allowed them to move into the conversation and social exchange. Additionally, one of the reasons for their interest in the marketplace is their wish to be a smart buyer who pursues to get maximum value. However, Walsh et al. (2004) claimed that since market mavens primarily acquired and communicated information on products they did not purchase for themselves as an essential characteristic, motives other than personal utility maximization drove mavens' behaviors. The potential motives leading them to share information with other consumers are an obligation to share information, pleasure in sharing knowledge and desire to help others. Similarly, Phelps et al. (2004) revealed in their research that the most frequently mentioned motives for interpersonal communication were a desire to connect and share with others. Other disclosed motivations ranged from the altruistic and comforting to the mundane and ordinary. While top-rated reasons were enjoyment and entertainment, 
two other social motives were to help and to communicate caring. Only a few mavens mentioned the obligation to gather information and pass it on to others.

Most of the empirical studies found no differences between mavens and non-mavens in relation to age, income, occupation, marital status or the number of children (Feick, Price, 1987; Higie et al., 1987; Walsh et al., 2004). However, some differences have been found out regarding gender and education variables. Williams and Slama (1995) proved that male mavens tended to be significantly younger, married for as shorter period and had lower education levels than non-mavens. While there was no difference between employed women and housewives regarding being a maven, female mavens were significantly different from non-mavens only in being married for a shorter period. Similarly, Walsh and Mitchell (2010) claimed that eMavens were slightly younger, less educated with a lower income and more likely to be female.

This study aims at understanding market maven behavior of travel agency employees by trying to identify their tendency to share information and give recommendations to tourism consumers. The study examined whether there was a difference between market maven behaviors of front-line employees of travel agencies regarding their demographic variables or not. In accordance with the research objectives and literature review on market mavenism concept, the following hypotheses are proposed:

$H_{i}$ : There is a significant relationship between gender and information passing behavior of travel agency employees.

$\mathrm{H}_{2}$ : There is a significant relationship between gender and recommendation passing behavior of travel agency employees.

$H_{3}$ : There is a significant relationship between age and information passing behavior of travel agency employees.

$H_{4}$ : There is a significant relationship between age and recommendation passing behavior of travel agency employees.

\section{Methodology}

A quantitative study on the employees of travel agencies located in Izmir has been conducted through a structured questionnaire. The contact details of travel agencies were acquired from the website of the Association of Turkish Travel Agencies (TURSAB) and 123 representatives from total 160 travel agencies accepted to fill the questionnaire. Data were obtained between the dates of 15 February 2016 - o1 March 2016. The questionnaire consisted of four separate sections. The first section contained five items adapted from the original six-item market maven scale (Feick, Price, 1987). The second section included six items and the third section contained twelve open-ended questions were adapted from the study of Goodey and East (2008). The last part involved five questions regarding essential demographic characteristics of the respondents. Since items were translated from English to Turkish and questionnaire in Turkish was utilized for the first time, they had to be retested for validity and reliability. The total 11 items rated on a five-point scale (1=strongly agree; 2 =agree; $3=$ =neither agree nor disagree; $4=$ disagree; $5=$ strongly disagree) resulted in two independent factors. Data obtained were analysed by using SPSS 24.0 software. Descriptive statistics, parallel test, minimum average partial test, exploratory factor analysis, independent sample t-test, and correlation analysis have been implemented on data. The responses given to the open-ended questions in the third section of the questionnaire were analyzed with content analysis and frequencies were revealed accordingly. A pilot study with 45 participants was conducted between the dates of 
15 February 2016 and 20 February 2016 before all the questionnaires handed out. KMO value of pilot validity test is 0.84 at a significance level of $\mathrm{p}<0.05$ and Cronbach Alpha value is 0.86 .

\section{Findings}

Demographic profile of employees under the base of descriptive statistics is shown in detail in Table 1. Most of the respondents are between the ages of 25-34 and female (64\%). Almost all of the respondents $(84 \%)$ were high school or university graduates. While $66 \%$ of the participants have been working in the tourism sector for six years and above, most of them have been working in the company which they are working right now for $0-2$ years $(36 \%)$ or 6 years and above (35\%). 66.4\% of the employees have been working in the tourism sector for six years and above. Examination of the histograms suggests that the skewness and kurtosis are assumed to be normal distributions.

Table 1: Profile of Respondents

\begin{tabular}{|c|c|c|}
\hline Variables & (n) & (\%) \\
\hline \multicolumn{3}{|l|}{ Age } \\
\hline $18-24$ & 11 & 9.3 \\
\hline $25-34$ & 63 & 53.0 \\
\hline $35-44$ & 38 & 32.0 \\
\hline 45 and above & 9 & 6.7 \\
\hline Total & 119 & 100.0 \\
\hline \multicolumn{3}{|l|}{ Gender } \\
\hline Male & 42 & 35.9 \\
\hline Female & 75 & 64.1 \\
\hline Total & 117 & 100.0 \\
\hline \multicolumn{3}{|l|}{ Education } \\
\hline High School & 11 & 9.3 \\
\hline University & 100 & 84.0 \\
\hline Master's \& PhD & 8 & 6.7 \\
\hline Total & 119 & 100.0 \\
\hline \multicolumn{3}{|c|}{ The Number of Years in the Tourism Sector } \\
\hline $0-2$ & 16 & 13.4 \\
\hline $3-5$ & 24 & 20.2 \\
\hline 6 and above & 79 & 66.4 \\
\hline Total & 119 & 100.0 \\
\hline \multicolumn{3}{|c|}{ The Number of Years in Travel Agency } \\
\hline $0-2$ & 43 & 36.2 \\
\hline $3-5$ & 34 & 28.5 \\
\hline 6 and above & 42 & 35.3 \\
\hline Total & 119 & 100.0 \\
\hline
\end{tabular}


Horn's (1965) Parallel Analysis and Velicer's (1976) minimum average partial test were carried out to determine the number of factors in order to test construct validity of the scales. Market maven scales were explained under two factors in the both of the tests. In the exploratory factor analysis, market maven scale was restricted to two factors. Maximum Likelihood method was used to calculate factors with Promax rotation method. According to Norman and Streiner's (1998) formula $(5.152 / \sqrt{\mathrm{N}-2})$ those with pattern matrix factors loading rates were less than 0.47 cut-off for the study. Finally, it was found that 10 items were formed under two factors with total variance in the rate of 0.73 . The results showed that market maven behavior of front line employees of travel agencies had two factors as recommendation giving and information passing (Table 2).

Table 2. Factor Analysis Results

\begin{tabular}{|c|c|c|c|}
\hline Factors & $\begin{array}{l}\text { Factor } \\
\text { Loadings }\end{array}$ & $\begin{array}{l}\text { Eigen } \\
\text { value }\end{array}$ & $\begin{array}{l}\text { Variance } \\
\text { Explained }\end{array}$ \\
\hline Factor 1: Recommendation & & 5.63 & 56.35 \\
\hline I felt it was my duty to pass on the information I had & 0.904 & & \\
\hline I was so happy with the product, I wanted to talk about it & 0.873 & & \\
\hline $\begin{array}{l}\text { I felt the information would help the customers I was making the } \\
\text { recommendation to }\end{array}$ & 0.872 & & \\
\hline I enjoy passing on such information & 0.853 & & \\
\hline $\begin{array}{l}\text { If the customers, I made the recommendation to, used that product/ service, it } \\
\text { would confirm to me that I had made a good choice }\end{array}$ & 0.840 & & \\
\hline Factor 2: Information & & 1.64 & 16.44 \\
\hline $\begin{array}{l}\text { I like helping customers by providing them with information about many kinds of } \\
\text { products }\end{array}$ & 0.900 & & \\
\hline $\begin{array}{l}\text { My friends think of me as a good source of information when it comes to new } \\
\text { products or sales }\end{array}$ & 0.890 & & \\
\hline $\begin{array}{l}\text { I like introducing alternative brands and products (apart from the hotels, etc. } \\
\text { which you deal) to customers }\end{array}$ & 0.808 & & \\
\hline $\begin{array}{l}\text { If customers asked where to get the best buy on several types of products, I } \\
\text { could tell him or her where to shop }\end{array}$ & 0.785 & & \\
\hline $\begin{array}{l}\text { I am a person who has information about a variety of products and likes to share } \\
\text { this information with customers }\end{array}$ & 0.744 & & \\
\hline
\end{tabular}

In the study, hypothesis tests were conducted to evaluate differences between market maven factors and gender and age of front-line employees in travel agencies. According to the results of independent samples t-test, there was a significant difference between gender and information passing and recommendation giving behavior of employees in travel agencies. Therefore, the hypotheses $\left(\mathrm{H}_{1}\right.$ and $\left.\mathrm{H}_{2}\right)$ were supported by sig. values 0.025 and 0.029 at a significance level of $p<0.05$ (Table 3 ).

Table 3. Results of Independent Samples T-test Analysis Based on Gender

\begin{tabular}{|c|c|c|c|c|c|c|c|}
\hline Factors & Gender & $\mathrm{N}$ & Mean & Sd. & Se. & $\mathrm{t}$ & Sig. \\
\hline Information & $\begin{array}{l}\text { Female } \\
\text { Male }\end{array}$ & $\begin{array}{l}75 \\
42\end{array}$ & $\begin{array}{l}4.26 \\
3.80\end{array}$ & $\begin{array}{l}0.63 \\
1.99\end{array}$ & $\begin{array}{l}0.07 \\
0.18\end{array}$ & 2.30 & $p=0.025$ \\
\hline Recommendation & $\begin{array}{l}\text { Female } \\
\text { Male }\end{array}$ & $\begin{array}{l}75 \\
42\end{array}$ & $\begin{array}{l}4.54 \\
4.14\end{array}$ & $\begin{array}{l}0.38 \\
1.13\end{array}$ & $\begin{array}{l}0.04 \\
0.17\end{array}$ & 2.24 & $p=0.029$ \\
\hline
\end{tabular}


The results indicated that there was not a significant difference between information passing and recommendation giving behavior and age of front-line employees in travel agencies. Therefore, the hypotheses $\left(\mathrm{H}_{3}\right.$ and $\left.\mathrm{H}_{4}\right)$ were not supported since sig. values were 0.146 and 0.665 at a significance level of $p<0.05$ (Table 4 ).

Table 4. Results of Independent Samples T-test Analysis Based on Age

\begin{tabular}{|c|c|c|c|c|c|c|c|}
\hline Factors & Age & $\mathrm{N}$ & Mean & Sd. & Se. & $t$ & Sig. \\
\hline Information & $\begin{array}{c}18-35 \\
36 \text { and above }\end{array}$ & $\begin{array}{l}74 \\
45\end{array}$ & $\begin{array}{l}4.01 \\
4.26\end{array}$ & $\begin{array}{l}0.98 \\
0.68\end{array}$ & $\begin{array}{l}0.11 \\
0.10\end{array}$ & -1.46 & $p=0.146$ \\
\hline Recommendation & $\begin{array}{c}18-35 \\
36 \text { and above }\end{array}$ & $\begin{array}{l}74 \\
45\end{array}$ & $\begin{array}{l}4.43 \\
4.36\end{array}$ & $\begin{array}{l}0.72 \\
0.83\end{array}$ & $\begin{array}{l}0.08 \\
0.12\end{array}$ & 0.45 & $p=0.665$ \\
\hline
\end{tabular}

Pearson correlation coefficients (Pearson's) were used to investigate the relationship between the level of information passing and recommendation giving behavior. The results of correlation analysis between two-factor attributes are shown in Table 5. According to results, there is a moderately strong to strong positive relationship (ranging between $\mathrm{r}=0.50$, and $\mathrm{r}=$ $0.74, \mathrm{p}<0.001$ ) between information passing behavior and recommendation giving behavior of travel agency employees.

Table 5. Results of Pearson Correlation Analysis

\begin{tabular}{|l|c|c|}
\hline & Information & Recommendation \\
\hline Information & 1 & \\
\hline Recommendation & $0.55^{* *}$ & 1 \\
\hline Mean & 4.11 & 4.41 \\
\hline Standard Deviation & 0.88 & 0.75 \\
\hline Cronbach's alpha & 0.88 & 0.92 \\
\hline
\end{tabular}

${ }^{* *}$ Correlation is at a significance level of $p<0.05$ (2-tailed).

The first part of the third section was consisted of the questions examining information sources which employees used while giving recommendations to their customers. They offered advice to consumers about hotels, destinations, and cruises which they mostly experienced themselves. The other sources such as advertisements and advices received from someone else such as friends, family or other consumers were other sources primarily used, respectively. Table 6 explains the detailed information about the recommendations made by travel agents. 
Table 6. The Information Sources Used by Travel Agents While Recommending

\begin{tabular}{|l|l|c|c|}
\hline \multirow{4}{*}{ Hotels } & Sources & Frequency (n) & Percentage (\%) \\
\hline \multirow{5}{*}{ Destinations } & I experienced myself & 54 & 56.2 \\
\cline { 2 - 4 } & Advertisements & 18 & 18.8 \\
\cline { 2 - 4 } & I got advice from someone else & 9 & 9.4 \\
\cline { 2 - 4 } & Other* & 15 & 15.6 \\
\hline \multirow{5}{*}{ Cruises } & I experienced myself & 65 & 62.5 \\
\cline { 2 - 4 } & Advertisements & 20 & 19.3 \\
\cline { 2 - 4 } & I got advice from someone else & 11 & 10.5 \\
\cline { 2 - 4 } & Other* & 8 & 7.7 \\
\hline & I experienced myself & 25 & 48.2 \\
\cline { 2 - 4 } & Advertisements & 11 & 21.2 \\
\cline { 2 - 4 } & I got advice from someone else & 8 & 15.3 \\
\cline { 2 - 4 } & Other* & 8 & 15.3 \\
\hline
\end{tabular}

* Other consists of the responses such as searching through the Internet, info travels organized by the company, through the official website of the company worked in.

The second part of the third section was consisted of open-ended questions about the details of recommendations that front-line employees working at travel agencies gave their customers. Travel agents recommended the hotels mostly located in Aegean and Mediterranean parts of Turkey. It was also figured out that travel agents suggested destinations in Turkey such as Antalya, Bodrum, Marmaris mainly, they also recommended European Cities, Maldives, the Far East and the Balkans abroad. Furthermore, respondents indicated that they only offered cruise companies with which their employers have agreements.

\section{Conclusions}

The purpose of this study was to understand whether the front line employees of travel agencies were market mavens or not. Our research indicates that travel agents should be accepted as market mavens with their information and recommendation giving behavior about hotels, destinations and cruise tours. Employees working at travel agencies located in Izmir have product knowledge and market expertise. According to Wiedmann et al. (2001), market mavens have not only product specific but also general marketplace information and are eager to share that information with other individuals. Market mavens become marketplace experts with their marketplace involvement and desire to use information for social exchange (Feick, Price, 1987). As one of the interpersonal communicators performing WOM, market mavens are market information providers who affect buying decisions of consumers seeking advice about a broad variety of products and services (Williams, Slama, 1995). Front-line employees working at travel agencies as market mavens play a significant role in supporting marketing communications and providing an advantage for the companies in the market.

The study of Clark et al. (2008) revealed that there was no correlation between mavenism and two demographic variables namely age and gender. Walsh et al. (2004) claimed that there were no relationships between being a maven and gender, age, annual household income, education, and occupation. In our study, it was found that gender was related to the travel agency front-line employees maven behavior, while there existed no difference in maven behavior 
of travel agency employees regarding their age, education, working time in the company and working time in the tourism sector. The study proved that females were more likely to give information and recommendation about tourism products to consumers. This result is consistent with the studies of Goodey and East (2008) and Higie et al. (1987) claiming that market mavens are more likely to be female.

Front-line employees working at travel agencies are more likely to advise and suggest tourism products and services which they have already experienced themselves. The previous studies (Alba, Hutchinson, 1987; Brucks, 1985; Kang, Herr, 2006; Martin, Lueg, 2013) also explained that product knowledge was derived from experience-based knowledge and familiarity with products. While the most recommended destinations were Antalya, Bodrum, and Marmaris for domestic travelers, travel agents advised European Cities, Maldives, the Far East and the Balkans for the individuals who wanted to have a holiday abroad. They mostly recommended five star and chain hotels. However, a few of them only suggested hotels and cruise companies with which they had contracts.

The conclusion of the study reveals that the travel agents are market mavens with their marketplace knowledge and information sharing behavior; however, they are unable to offer tailored products and services to their consumers due to their strict agreements with other tourism service providers. Companies should invest in market mavens in the tourism industry and give travel agents broader authorities to affect consumer buying decisions and increase their sales.

\section{Limitations and Future Research}

Our study is limited regarding generalizability and has some shortcomings. According to the website of TURSAB, a total of 384 travel agencies were located in Izmir; however, some of them were inaccessible due to various reasons such as closure, merging or address changes. For this reason, we could only reach 160 travel agencies, and 123 representatives accepted to fill the questionnaire. Also, we underestimated e-maven behavior of travel agents, in the further research their social media involvement to share product knowledge and marketplace expertise should be investigated.

\section{References}

Alba, J., Hutchinson, J.W. 1987. Dimensionsof Consumer Expertise. Journal of Consumer Research 13(4), 411-454.

Brucks, M. 1985. The Effect of Product Class Knowledge on Information Search Behavior. Journal of Consumer Research12(1), 1-16.

Clark, R. A., Goldsmith, R. E. 2005. Market Mavens: Psychological Influences. Psychology and Marketing 22(4), 289-312.

Clark, R. A., Goldsmith, R. E., Goldsmith, E. B. 2008. Market Mavenism and Consumer SelfConfidence. Journal of Consumer Behaviour 7(3), 239-248.

Corey, L. G. 1971. People Who Claim to Be Opinion Leaders: Identifying TheirCharacteristics by Self-Report. Journal of Marketing 35(4), 48-53.

Elliott, M. T., Warfield, A. E. 1993. Do Market Mavens Categorize Brands Differently? Advances in Consumer Research 20(1), 202-208. 
Feick, L. F., Price, L. L. 1987. The Market Maven: A Diffuser of Marketplace Information. The Journal of Marketing 51(1), 83-97.

Flynn, L. R., Goldsmith, R. E. 2017. Filling Some Gaps in Market Mavenism Research. Journal of Consumer Behaviour 16, 121-129.

Gauri, D. K., Harmon-Kizer, T. R., Talukdar, D. 2016. Antecedents and Outcomes of Market Mavenism: Insights Based on Survey and Purchase Data. Journal of Business Research 69(3), 1053-1060.

Goldsmith, R. E., Flynn, L. R., Goldsmith, E. B. 2003. Innovative Consumers and Market Mavens. Journal of Marketing Theory and Practice 11(4), 54-65.

Goodey, C., East, R. 20o8. Testing the Market Maven Concept. Journal of Marketing Management 24(3), 265-282.

Hair, J. F., Black, B., Babin, B., Anderson, R.E., Tatham, R.L. 2007. Multivariate Data Analysis. New Jersey:Pearson Education Inc.

Higie, R. A., Feick, L. F., Price, L. L. 1987. Types and Amount of Word-Of-Mouth Communications about Retailers. Journal of Retailing 63(3), 260-278.

Ho, J. Y., Dempsey, M. 2010. Viral Marketing: Motivations to Forward Online Content. Journal of Business Research 63(9), 1000-1006.

Horn, J. L. 1965. A Rationale and Test for the Number of Factors in Factor Analysis. Psychometrica 30(2), 179-185.

Kang, Y., Herr, P. M. 2006. Beauty and the Beholder: Toward an Integrative Model of Communication Source Effects. Journal of Consumer Research 33(1), 123-130.

Lee, S. H., Leizerovici, G., Zhang, S. 2015. The Satisfaction and Stress of Being a Market Maven: A Social Network Perspective. Journal of Consumer Behaviour 14, 325-334.

Martin, W., Lueg, J. E. 2013. Modeling Word-of-Mouth Usage. Journal of Business Research 66(7), 801-808.

Norman, G. R., Streiner, D. L. 1998. Biostatistics - The Bare Essentials. Hamilton: B.C. Decker Inc.

Nunnally J. C. 1976. Psychometric Theory (Second Edition). New York: McGraw-Hill.

O'Sullivan, S. R. 2015. The Market Maven Crowd: Collaborative Risk-Aversion and Enhanced Consumption Context Control in an Illicit Market. Psychology E Marketing 32(3), 285-302.

Phelps, J. E., Lewis, R., Mobilio, L., Perry, D., Raman, N. 2004. Viral Marketing or Electronic Word-Of-Mouth Advertising: Examining Consumer Responses and Motivations to Pass Along Email. Journal of Advertising Research 44.4), 333-348.

Schiffman, L. G., Kanuk, L. L. 2010. Consumer Behavior (1oth Edition). New Jersey: Prentice Hall Inc.

Schneider, K. C., Rodgers, W. C. 1993a. A Research Note on Market Mavens and the Dissemination of Positive versus Negative Marketplace Information. The Journal of Marketing Management 3(2), 67-72.

Schneider, K. C., Rodgers, W. C. 1993b. Generalized Marketplace Influencers' (Market Mavens') Attitudes toward Direct Mail as a Source of Information. Journal of Direct Marketing 7(4), 20-28.

Silverman, G. 2011. The Secrets of Word-of-Mouth Marketing (Second Edition). New York: Amacom.

Slama M., Nataraajan R., Williams T.G. 1992. Market Mavens and the Relationship Between Smart Buying and Information Provision: An Exploratory Study. In V.L. Crittenden (Eds.), Developments in Marketing Science:Proceedingsof the Academy of Marketing Science. Chestnut Hill: Springer. 
Solomon, M., Bamossy, G., Askegaard, S., Hogg, M. 2006. Consumer Behaviour: A European Perspective. New Jersey: Prentice Hall.

Sudbury-Riley, L. 2016. The Baby Boomer Market Maven in The United Kingdom: An Experienced Diffuser of Marketplace Information. Journal of Marketing Management 32(7-8), 716749.

Velicer, W.F. 1976. Determining the Number of Components from the Matrix of Partial Correlations. Psychometrika 41(3), 321-327.

Villanueva, J., Yoo, S., Hanssens, D. M. 2008. The Impact of Marketing-Induced Versus WordOf-Mouth Customer Acquisition on Customer Equity Growth. Journal of Marketing Research 45(1), 48-59.

Walsh, G., Elsner, R. 2012. Improving Referral Management by Quantifying Market Mavensword of Mouth Value. European Management Journal 30, 74-81.

Walsh, G., Mitchell, V. W. 2010. Identifying, Segmenting and Profiling Online Communicators in an Internet Music Context. International Journal of Internet Marketing and Advertising 6(1), 41-64.

Walsh, G., Mitchell, V. W., Wiedmann, K. P., Frenzel, T., Duvenhorst, C. 2002. German eMavens on Internet Music Sites. In W. J. Kehoe \& J. H Lindgren (Eds.), AMA 2002 summer educators' conference 13: Proceedings: Enhancing knowledge development in marketing. Chicago: American Marketing Association.

Walsh, G., Gwinner, K. P., Swanson, S. R. 2004. What Makes Mavens Tick? Exploring the Motives of Market Mavens' Initiation of Information Diffusion. Journal of Consumer Marketing 21(2), 109-122.

Wiedmann, K. P., Walsh, G., Mitchell, V. W. 2001. The Mannmaven: An Agent for Diffusing Market Information. Journal of Marketing Communications 7(4), 195-212.

Williams, T. G., Slama, M. E. 1995. Market Mavens' Purchase Decision Evaluative Criteria: Implications for Brand and Store Promotion Efforts. Journal of Consumer Marketing 12(3), 4-21.

Yang, H. 2013. Market Mavens in Social Media: Examining Young Chinese Consumers' Viral Marketing Attitude, eWom Motive, and Behavior. Journal of Asia-Pacific Business 14(2), 154-178. 